\title{
Marine Microbiology at Scripps
}

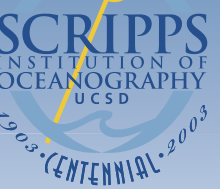

\author{
A. Aristides Yayanos \\ Scripps Institution of Oceanography, University of California, · San Diego, California USA
}

Marine microbiology is the study of the smallest organisms found in the oceans-bacteria and archaea, many eukaryotes (among the protozoa, fungi, and plants), and viruses. Most microorganisms can be seen only with a microscope. Microbes pervade the oceans, its sediments, and some hydrothermal fluids and exhibit solitary life styles as well as complex relationships with animals, other microorganisms, and each other. The skeletal remains of microorganisms form the largest component of sedimentary fossils whose study reveals Earth's history. The enormous morphological, physiological, and taxonomic diversity of marine microorganisms remains far from adequately described and studied. Because the sea receives terrestrial microorganisms from rivers, sewage outfalls, and other sources, marine microbiology also includes the study of alien microorganisms.

My goals here are to outline how marine microbiology at Scripps Institution of Oceanography has grown throughout the past 100 years; to review the contributions of some of its scientists to the solution of microbiological problems during the twentieth century; and to consider, albeit briefly, in which directions marine microbiology will expand next.

\section{The Field of Microbiology in 1903}

Antony van Leeuwenhoek invented the light microscope that enabled him to discover the world of small organisms in the early eighteenth century. Bacteriology arose as an identifiable scientific field in the second half of the nineteenth century (Russell 1893a; Russell 1893b), a few decades before the beginning of the Marine Biological Station of San Diego in 1903. Many of the principles, problems, and methods still in use today were firmly established by 1903 with notable work by Louis Pasteur, Robert Koch (who was awarded the Nobel Prize in 1905), Sergei Winogradsky, and Martinus Beijerinck. The latter two introduced the method of enrichment culture, whereby a particular bacterium could be grown in the laboratory by providing it with the essential growth conditions present in its natural environment, and employed it to discover and isolate new groups of microorganisms. Winogradsky (Waksman, 1946) discovered chemoautotrophic bacteria, which grow with carbon dioxide as the sole carbon source and inorganic chemicals as the energy source. Beijerinck (van Iterson et al., 1983) isolated marine bioluminescent bacteria, isolated and characterized sulfate-reducing bacteria, and showed denitrifying bacteria could both produce and consume nitrous oxide, now known to be an important greenhouse gas. Beijerinck also founded the field of virology through his work on plant viruses (van Iterson et al., 1983). Mills (1989) describes the significance of the work of Beijerink and Winogradsky to plankton research and marine chemistry.

Around 1903, bacteriology in California was emerging in the areas of medicine and public health and accordingly was developing into an academic discipline in medical schools (McClung and Meyer, 1974). Whereas the branch of microbiology dealing with bacteria and viruses was just beginning, the branch concerning protozoa and algae was a relatively more established field. Charles A. Kofoid, a professor at the University of California, Berkeley and a colleague of William E. Ritter, founding director of Scripps, played a key role in helping Ritter achieve his goals and worked often at the Marine Biological Station of San Diego (Spiess, 2002). As a protozoologist, Kofoid is the first microbiologist to work at Scripps (Figure 1). He participated in several expeditions, notably one to the eastern Pacific for several months with the well-known biological oceanographer Alexander Agassiz (Agassiz and Agassiz, 1913). Kofoid continued to publish results on the oceanic distribution of protozoa many years after this voyage (Kofoid, 1934). According to Mills (1989), Kofoid was one of the first scientists to observe that nets inadequately sampled plankton (Kofoid, 1897).

The work of these pioneer microbiologists was experimental, ecological, and environmental. That combination of perspective- the view offered through laboratory experiments and the view from observing microorganisms in natural settings-continues to characterize marine and medical microbiology. Some scientists devote their time to a very focused problem in microbiology and do not address questions directly bearing on the natural setting of the organism. Yet their fundamental results, new techniques, and conclusions inevitably shed understanding on ecological problems. Ritter's strong belief in the "necessity of closer co-operation between field work and laboratory work" (Ritter, 1912) was amply validated throughout the twentieth century and is a dictum today for research at a marine station. 


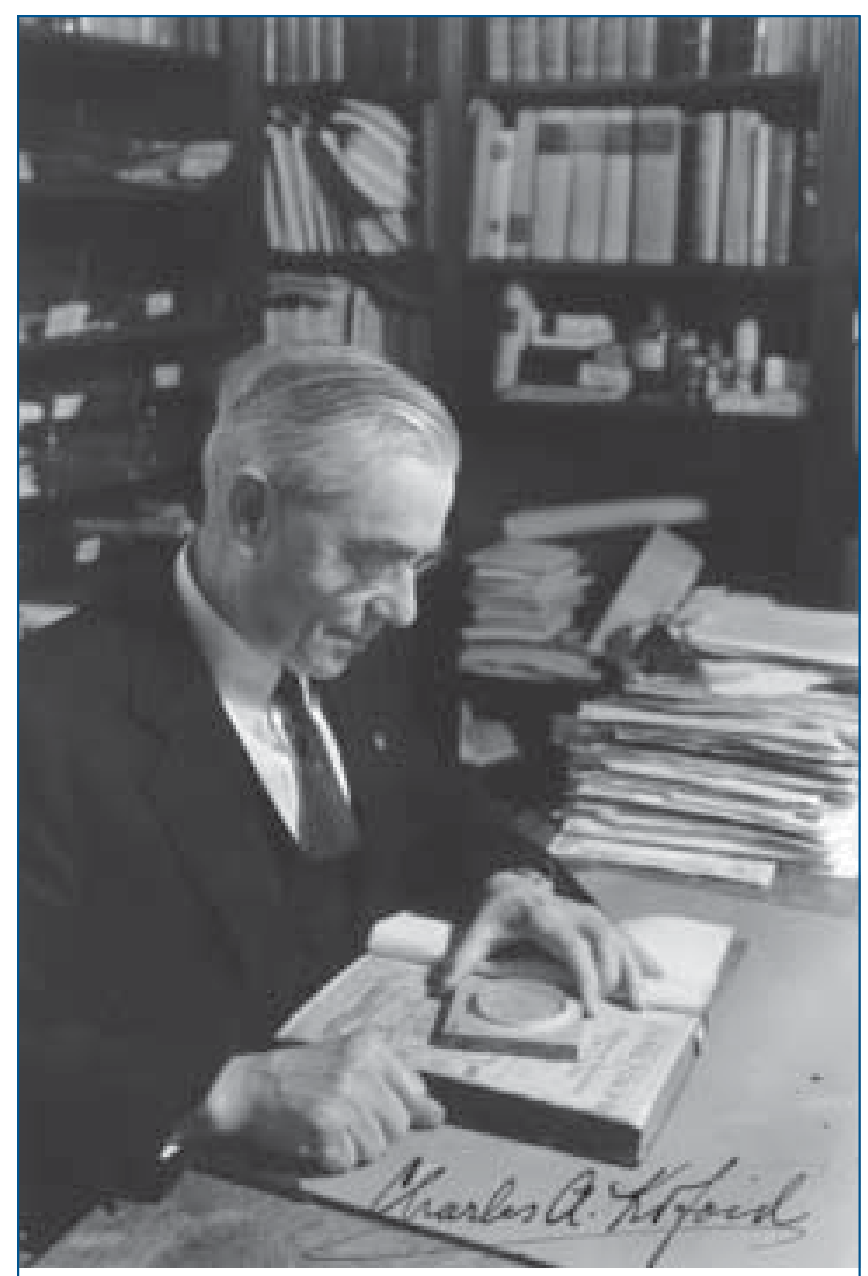

Figure 1. Charles A. Kofoid is the first microbiologist to work at Scripps.

\section{The Early Development of Microbiology at Scripps}

In 1912 Ritter used "nannoplankton [sic]" as the term to describe the bacteria of the sea and referred to the study of them as "probably the most important field still untouched by the station." The Marine Biological Station of San Diego was renamed in 1912 as Scripps Institution for Biological Research and then as Scripps Institution of Oceanography shortly after Thomas Wayland Vaughan succeeded Ritter as Director (Ritter 1936; Vaughan 1926a;Vaughan 1926b).

In 1928 Vaughan hired A.Haldane Gee as assistant professor of bacteriology. This first bacteriologist to work at Scripps left in 1932 because of illness (Yayanos, 2000b). During his short time at Scripps, Gee studied the biogeochemistry of carbon dioxide and carbonates (Gee, 1932b; Gee, 1932c). He published two papers on techniques in the Journal of Bacteriology and described a water sampler suitable, he believed, for deep-sea micro-

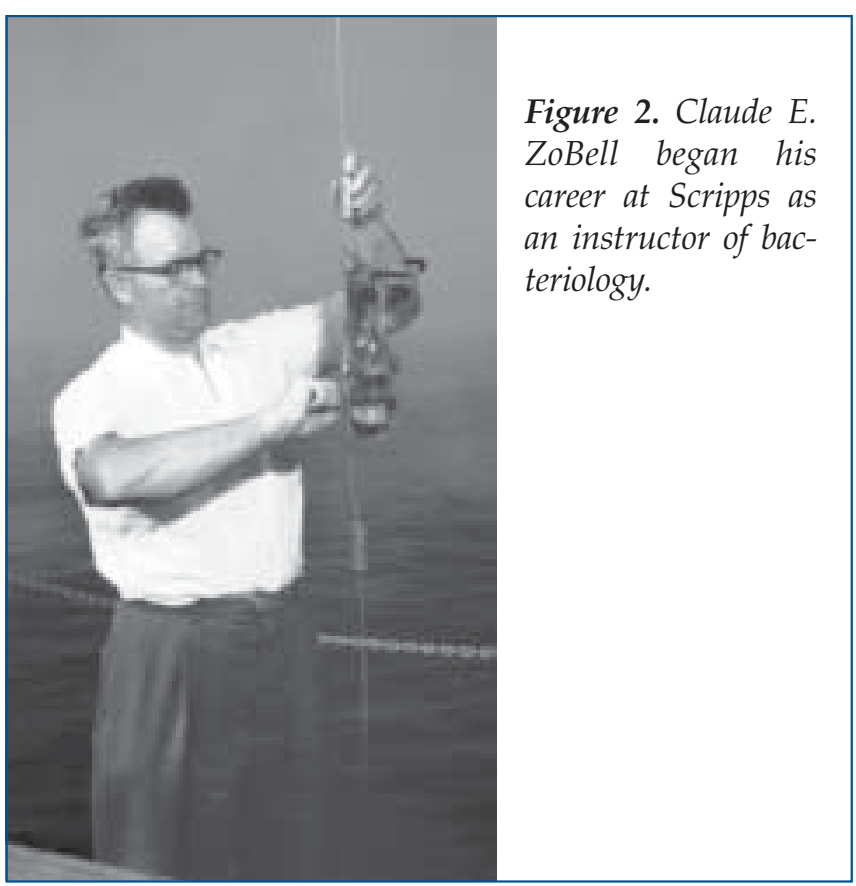

biology (Gee, 1932a). Gee left with his successor, Claude E. ZoBell, a manuscript reviewing the field of marine bacteriology. ZoBell edited the unpublished manuscript and deposited a copy in the Scripps library. ${ }^{1}$

At this time the field of bacteriology was beginning to mature. The biochemistry of bacteria was showing exciting progress as can be seen by examining Marjory Stephenson's book first published in 1929 (Stephenson, 1949). The microscopy of bacteria advanced considerably with the commercialization of Fritz Zernike's phase contrast microscope which allowed microbiologists to easily visualize living bacterial cells. The philosophical outlook of Albert J. Kluyver towards microbiology was taking hold. Kluyver was one of the foremost exponents of the idea that there is unity in the diverse metabolic processes found among microorganisms. He gave evidence in 1924 for chemical energetics providing one such unifying view (for a translation, see Kluyver, 1959). Kluyver saw microbiology as a basic science-not simply an applied field for medicine, agriculture, and industry. Finally, the significance of bacteria in the sea was beginning to emerge through studies by Selman A. Waksman (Waksman and Renn, 1936), Wilhelm Benecke (Benecke, 1933), Leslie H.N. Cooper (Cooper, 1937), Blodwyn Lloyd (Lloyd, 1931) and others (see Mills, 1989, and ZoBell, 1946).

On January 1, 1932, a little more than a month after defending his thesis at University of California, Berkeley, Claude E. ZoBell began his career at Scripps as an instructor of bacteriology (Figure 2). Years later ZoBell said, "My first job was to determine the extent to which bacteria are active in the open ocean and to assess their possible importance as geochemical 
agents...[and]...I am still working on this" (ZoBell, 1968). ZoBell focused his research on the relationship between marine bacteria and their ocean environment. By 1950, six of the 36 Ph.D. theses completed in all subjects at Scripps were done under Zobell's direction on a variety of bacteriological problems. Sydney C. Rittenberg, professor emeritus at University of California, Los Angeles, was ZoBell's first student and did his thesis work on the microbiology of sediment cores (Rittenberg, 1940).

ZoBell's work covered a wide-ranging set of problems in marine bacteriology and petroleum microbiology. He wrote Marine Microbiology, the first monograph in this field (ZoBell, 1946). In the foreword of the book, Waksman (who was awarded the Nobel Prize in 1952) noted, "ZoBell has rendered a distinct service to the bacteriologist, to the oceanographer, and to all those who are interested in the cycle of life in natural water basins." In the preface, ZoBell acknowledged his debt to Gee's unpublished review of the field of marine bacteriology. A few years ago, a symposium was held in ZoBell's honor (LappinScott, 2000). The organizers were scientists from the United Kingdom who had never met ZoBell yet were compelled to review his career because of his influence on their work. ZoBell founded the Geomicrobiology Journal and was its editor for several years after his retirement.

As an example of Zobell's influence, his work set the research agenda in deepsea microbiology for the next generation of scientists (McGraw, 2002; Yayanos, $2000 \mathrm{~b}$ ) through his expositions on the biological importance of pressure in the deep sea. His writings are often characterized by a synoptic view of scientific and practical problems. His pioneering deep-sea microbiological studies were conducted mostly with his students Carl H. Oppenheimer and Richard Y. Morita. Both had distinguished careers as marine microbiologists. Morita is a professor emeritus at Oregon State University. Among Morita's numerous accomplishments is the influential work he did on the survival of marine bacteria under conditions of starvation. Morita, Oppenheimer, and ZoBell introduced high-pressure technique as an essential element in the study of deepsea bacteria. These advances were the foundation of my own work (Yayanos, 2000a) and that of Douglas H. Bartlett and his students, who now use the modern tools of molecular genetics to garner insights into the basis of pressure adaptation (Bartlett, 2002).

Scientists from all over the world visited ZoBell's laboratory. Galen E. Jones and Holger W. Jannasch collaborated while in ZoBell's laboratory to show that the enumeration of bacteria in seawater samples with a single type of growth medium results in a severe underestimate (Jannasch and Jones, 1959). Only recent- ly has the dual problem of enumerating and identifying bacteria in the sea been significantly advanced. Edward F. DeLong (who earned his Ph.D. at Scripps in 1987) and Steven Giovannoni, as postdoctoral fellows with Norman Pace at Indiana University, developed the use of fluorescently labeled nucleic probes for detecting and enumerating bacteria in environmental samples. Their work over the past 15 years continues to revolutionize marine microbial ecology (DeLong 1992; DeLong 2001).

\section{The Expansion of Microbiology at Scripps}

A grant from the Rockefeller Foundation in the early 1950s fostered biological research at Scripps. The U.S. government began to give unprecedented support for scientific research after World War II. Thereby, research at Scripps Institution expanded and concomitantly the number of microbiologists at the institution increased during the 1960s and '70s. By 1966 approximately a dozen scientists were researching some aspect of microbial life in the sea. Experimental biology, including microbiology, received a huge boost in 1977 with the dedication of the Marine Biology Building, now known as Hubbs Hall, with its modern laboratory facilities. Andrew A. Benson and Scripps Director William A. Nierenberg were instrumental in getting funds for the building. The institution's fleet of ships grew in size and capabilities allowing for work at sea on a global scale. In the following sections, I survey a few of the subjects in which Scripps microbiologists have made contributions.

\section{The Air-Sea Interface}

Ferren MacIntyre, a Scripps assistant professor of marine chemistry between 1966 and 1969, described with vivid illustrations the biochemical and physical processes, such as the formation and bursting of bubbles, that occur in the sea-surface microlayer, and that may lead to a better understanding of climate and weather (MacIntyre, 1974). Work by Angelo F. Carlucci, a marine microbiologist, Peter M. Williams, a marine chemist (who earned his Ph.D. at Scripps in 1961), and several colleagues greatly advanced the quantitative understanding of the biochemicals, nutrients, and microorganisms found in sea surface microlayers (Williams et al., 1986). The air borne transport of bacteria from sea to land and vice versa was studied at Scripps in the 1930s (ZoBell and Mathews, 1936) and more recent work shows how bursting bubbles concentrate bacteria from the sea surface microlayer and move them to the air (Bezdek and Carlucci, 1972; Blanchard and Syzdek, 1990). The subject of aeolian transport of 
bacteria to and from the sea will undoubtedly be taken up more frequently and with modern methods of detecting bacteria because the process is potentially important to meteorology and lateral gene transfer, as well as applicable to national defense concerns.

\section{Microbiology of the Upper Ocean}

Easter Ellen Cupp was the first student at Scripps to write a thesis in microbiology in 1934 (Figure 3). She studied diatoms, photosynthetic microorganisms that are a significant component of the phytoplankton, and her subsequent publications on diatoms and dinoflagellates remain useful today. Since Cupp's thesis, there have been approximately 10 additional theses concerning diatom biology. Elizabeth L. Venrick's 1969 thesis, under the guidance of Edward W. Fager, was on the biogeography of diatoms in the North Pacific Ocean. W. Marshall Darley, Barbara B. Hemmingsen, Cornelius W. Sullivan, John S. Paul, and Thomas W. Okita completed their doctoral studies mostly on the biochemistry and molecular biology of silicon in diatoms. This work took place in the laboratory of the late Benjamin E. Volcani who came to Scripps in the 1950s. Volcani received his Ph.D. in Israel on the general microbiology of the Dead Sea.

Beatrice M. Sweeney, who earned her Ph.D. from Radcliffe College in 1942, worked at Scripps during the 1950s. She determined that vitamin $B^{12}$ was necessary to grow the dinoflagellate Gymnodinium splendens (now known as Akashiwa sanguineum) in a chemically defined seawater medium (Sweeney, 1954). Sweeney began studies on circadian rhythms in the dinoflagellate Lingulodinium polyedrum with J. Woodland Hastings (Sweeney and Hastings, 1957). In collaboration with Francis T. Haxo (now Scripps professor emeritus), Sweeney studied circadian rhythms also in the marine alga Acetabularia major (Sweeney and Haxo, 1961). They showed cells maintain a periodicity in photosynthetic rate under continuous illumination when preceded by several day-night cycles of illumination. With Haxo as their advisor, David J. Chapman, Laurel A. Loeblich, Barbara B. Prezelin and Nancy W. Withers performed research on the pigments of unicellular algae for their doctoral studies. Scripps biologist William Thomas, in collaboration with physicist Carl Gibson, demonstrated that the growth of dinoflagellates, including L. polyedrum, was decreased by flow conditions simulating those near the ocean surface on a windy day. Their laboratory experiments were important in providing a model system for examining how turbulence affects cell physiology. Currently, Michael I. Latz, along with his students and colleagues, are studying the influence of hydrodynamic parameters on the growth and bioluminescence of dinoflagellates. This line of research examines cell biology in an ecological perspective.

Many distinguished scientists who spent part of their careers at Scripps did benchmark work long

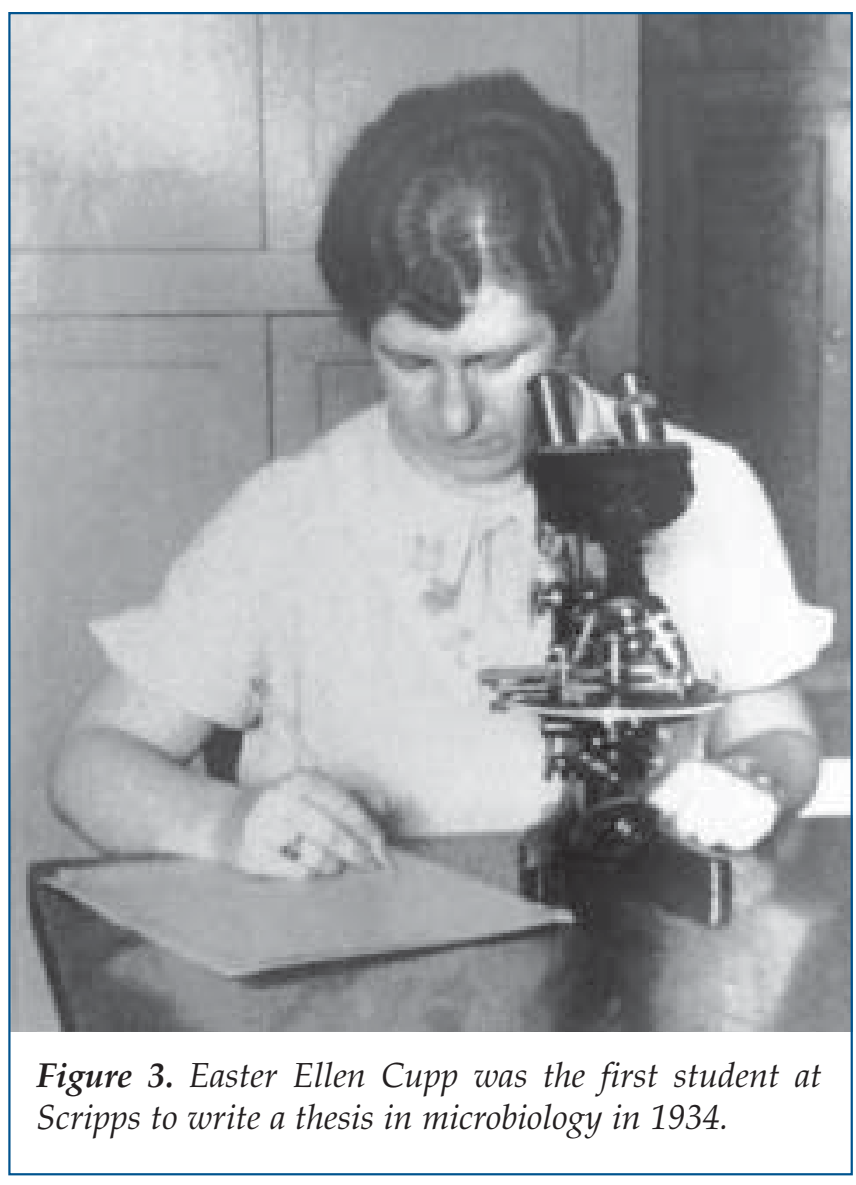

before coming here. For example, prior to coming to Scripps, Martin D. Kamen, in collaboration with Sam Ruben, discovered ${ }^{14} \mathrm{C}$, the radioactive isotope of carbon that became widely used as a radioactive tracer in the study of the metabolism of carbon compounds (Kamen, 1985). Professor Emeritus of Marine Biology Andrew A. Benson, who is still active in research as he approaches his eighty-fifth year, also established his reputation as a scientist long before coming to Scripps. Working with several scientists at University of California, Berkeley, he used ${ }^{14} \mathrm{C}$-labelled carbon dioxide as a tracer and devised clever experimental techniques (Fuller, 1999) to discover how plants make sugars from sunlight and carbon dioxide (Benson and Calvin, 1947; Calvin and Benson, 1949). This biochemical pathway is now called the Calvin-Benson cycle. The work of Kamen and Benson set the foundation for using ${ }^{14} \mathrm{C}$-labelled carbon dioxide to determine primary production in the world's oceans (Steemann Nielsen, 1952). Benson's contributions to microbiology since coming to Scripps include his studies of arsenic metabolism in unicellular algae (Cooney, 1981; Knowles and Benson, 1983).

John D.H. Strickland spent the last few years of his life heading up the Food Chain Research Group (FCRG) in the Institute of Marine Resources at Scripps. Microbiological research of an oceanographic character was conducted by Richard W. Eppley, Osmund Holm- 
Hansen, Robert D. Hamilton, John R. Beers, William H. Thomas, Farooq Azam, Angelo F. Carlucci, Bess B. Ward, and others. A hallmark of their work was concern with questions of both autotrophic and heterotrophic microbial life in the pelagic sea. Of this group of scientists, only Holm-Hansen and Azam maintain active research programs at Scripps today, and Ward is now on the faculty at Princeton University.

FCRG microbiologists produced a significant number of doctoral students who have developed distinguished careers. David M. Karl (who earned his Ph.D. at Scripps in 1978) mentored by Holm-Hansen, is now at the University of Hawaii. He has written seminal papers on pelagic, deep-sea, and hydrothermal vent microbiology (Karl, 1995). Robert J. Olson (who earned his Ph.D. at Scripps in 1980), another student of Holm-Hansen's, and Ward have conducted benchmark work on nitrifying bacteria (Mills, 1989). While at

Woods Hole Oceanographic Institution (WHOI), Olson collaborated with Sallie W. Chisholm at MIT and other researchers to discover a new cyanobacterium, Prochlorococcus, a significant component of the phytoplankton. Prochlorococcus is responsible for 25 percent of primary production (Goericke and Welschmeyer, 1993). Chisholm spent her postdoctoral years with FCRG under the mentorship of Eppley. For a few years, Ralph A. Lewin and others found evidence that Prochloron, so named by Lewin, was the single-cell ancestor of chloroplasts, the organelles fixing carbon dioxide in plant cells. Recent findings, however, suggest that Prochloron, symbiotic and photosynthetic, is a cyanobacterium (Lewin, 2002).

Brian Palenik and Bianca Brahamsha in the Marine Biology Research Division of SIO are currently part of a collaborative program investigating the genome sequence of Synechococcus, a cyanobacterium. Bianca Brahamsha is also conducting experiments to determine how Synechococcus swims. Many bacterial and protozoan species have the ability to move on surfaces and in water by using flagella or cilia. Motile cells of Synechococcus have no visible organelle that can generate thrust. Brahamsha identified a cell wall protein whose absence inhibits translational but not rotational motion of Synechococcus (Brahamsha, 1996). Currently, she and her students are working to find more of the molecular components of the motility apparatus.

The work of Jed A. Fuhrman (who earned his Ph.D. at Scripps in 1981) and advisor Azam has had a huge impact on the field of bacterial production. They used radioactively labeled thymidine, a precursor for the synthesis of DNA, to determine the amount of DNA synthesized by bacteria in samples of seawater and thereby to estimate the production of bacterial biomass in the sea (Fuhrman and Azam, 1982).

\section{Protozoology of the Deep Sea}

Professor Emeritus of Biological Oceanography Robert R. Hessler, with his students and collaborators, made major contributions to the understanding of deep-sea biodiversity (Smith et al., 1998). Among his many microbiological contributions is the discovery and description of a superfamily of foraminifera living in abyssal sediments (Tendal and Hessler, 1977). One of Hessler's former students, Joan M. Bernhard (who earned her Ph.D. at Scripps in 1990), studies living deep-sea foraminifera in relation to the oxygen content of their environment (Bernhard et al., 2003). Lisa A. Levin (who earned her Ph.D. at Scripps in 1982), now a professor of biological oceanography at Scripps, studies, in addition to foraminifera, a remarkable group of deep-sea protozoa called Xenophyophoria that grow to tens of centimeters in diameter (Levin, 1994).

\section{Microbiology of Hydrothermal Vents}

The discovery of hydrothermal vent fauna in the late 1970s attracted the interest of scientists worldwide, including some at Scripps. In 1981 Scripps scientist Horst Felbeck, as a postdoctoral fellow with Scripps professor George N. Somero, reported that the tissues of hydrothermal vent tube worms contain key enzymes of the Calvin-Benson cycle and could make carbon compounds from carbon dioxide and the oxidation of hydrogen sulfide (Felbeck, 1981). Felbeck and Somero (now director of the Hopkins Marine Station) made fundamental contributions to the physiology and biochemistry of hydrothermal vent symbiotic bacteria possessing these enzymes and inhabiting the tissues of hydrothermal vent animals. Among the former Scripps graduate students who continue to contribute to hydrothermal vent microbiology are Craig S. Carey (Campbell et al., 2001; Cary et al., 1997), Jeffrey L. Stein (Stein et al., 1988), Daniel L. Distel (Distel and Felbeck 1988a; Distel and Felbeck, 1988b) and David M. Karl (Karl, 1995).

\section{Bacterial Bioluminescence}

In the early 1970s, Kenneth H. Nealson joined the Scripps faculty. During his postdoctoral years at Harvard University, Nealson along with T. Platt and J. Woodland Hastings discovered and named the process of autoinduction of bioluminescence (Hastings and Nealson, 1977). They observed that the bioluminescence per cell in a growing culture increases dramatically above a certain concentration of cells. This observation led ultimately to the identification of the chemical structure of the autoinducer and, more significantly, to the fundamental phenomenon that is today termed quorum sensing. The basic idea is that bacteria 
communicate with one another through autoinducer chemicals. This work has implications ranging from microbial community ecology to medical microbiology. Nealson and one of his first students, Edward G. Ruby (who earned his Ph.D. at Scripps in 1977) published important papers on luminous bacteria in the sea. After his doctoral work, Ruby studied hydrothermal vent bacteria with Jannasch at WHOI. Then he did research on Bdellovibrio, a bacterium spending part of its life cycle within other bacteria, in the laboratory of S.C. Rittenberg (former student of ZoBell) at UCLA. Ruby is today prominent in the study of luminescent bacteria that are symbiotic. Another of Nealson's students, Margo G. Haygood (who earned her Ph.D. at Scripps in 1984), completed her thesis work on bacterial bioluminescence and is now a professor at Scripps with research programs on iron transport across bacterial membranes, the natural product chemistry of symbiotic bacteria, and bioluminescence. Another Scripps student, JoAnne Engebrecht (who earned her Ph.D. in 1986), did spectacular benchmark research for her doctoral degree (with Michael Silverman, an adjunct professor) on the molecular genetics of bacterial bioluminescence (Engebrecht and Silverman, 1984).

Nealson's influence at SIO remains not only through the research of Haygood but also through that of Bradley M. Tebo, another of his students. Tebo has a vigorous research program in the biogeochemistry of metals in the context of bioremediation, hydrothermal vent microbiology, and molecular genetics.

\section{Viruses of Marine Organisms}

There was little evidence in 1946 (ZoBell, 1946) to believe that viruses were a significant component of marine ecosystems. Lewin described a marine bacteriophage (i.e., a bacterial virus) in 1960. Although there was modest progress in this field for the next 20 years, the field of marine virology changed significantly in the 1990s. Fuhrman recently reviewed the field of marine bacterial viruses (Fuhrman, 1999) and documents the role played in this advance by Azam and his former students David C. Smith (who earned his Ph.D. at Scripps in 1994) and Grieg F. Steward (who earned his Ph.D. at Scripps in 1996). Fuhrman states that there are at least 10 billion viruses per liter of seawater.

\section{The Future of Marine Microbiology}

A little more than 100 years ago, William T. Sedgwick (Sedgwick, 1901) believed "by virtue of the discoveries upon which it [bacteriology] was founded, to which it has led and upon which today it rests illustrious and secure, mankind has been enabled for the first time to arrive at an adequate comprehension and understanding of the microscopic world and of many important and familiar natural phenomena hitherto either not understood or misinterpreted." In the twentieth century the biochemical and molecular biological foundations for these processes were established. Work with microbes led, for example, to elucidation of biochemical pathways, identification of the mechanisms of bioenergetics, discovery of restriction enzymes, and understanding of a host of processes fundamental to all life. Many of the marine microbes participating in biogeochemical cycles were identified. Microorganisms produce and consume greenhouse gases and modify the chemical composition of seawater, or, as Scripps Institution Director Vaughan wrote, "The environment affects the organisms, which react and not merely change the environment, but, through their activities, are in large measure responsible for making it what it is" (Vaughan, 1930).

The genomic revolution began in 1953 with the Watson-Crick functional model of DNA. In 1958 a symposium was held at Scripps "to produce definite suggestions for the possibly forthcoming fields of development in marine biology" (BuzzatiTraverso, 1958). Neither the DNA nor the microbiological revolutions we now see so clearly were anticipated in any way!

Since then a steady progression of DNA-based analytical techniques has permeated the venerable fields of phylogeny, evolution, and biogeography to place them on the threshold of an enormous information explosion. Evidently, the twenty-first century will be a time not only for continued discoveries in field and laboratory microbiology, but also one for the transformation of theoretical biology into a mature discipline. Mathematicians and computer scientists are now in biology departments and the field of bioinformatics has been born. The insights gained from bioinformatic analyses of genomes will contribute to a better understanding of biological evolution and possibly lead to a mathematical theory of evolution. The achievements in biological sciences are often seen as descriptive; the complex nature of the processes has eluded mathematical description. Those looking back on the twenty-first century will likely see an incipient mathematical biology not well perceived today.

The complete genome sequences of several bacteria, including a few from the sea, have already been determined. Among the current research issues of primary importance is that of lateral gene transfer; for example, the transfer of genes from a bacterium of one species to that of another. The mechanisms for these exchanges and their consequences will undoubtedly be worked out in the near future.

In 1929, Stephenson wrote in the preface to her 
book that "the place of bacteria in evolution is a question very difficult to approach; we have, for example, no idea whether the forms familiar to us resemble primitive bacterial types or whether, like modern animals and plants, they are the successful competitors of the ages...[and]...owing to their relatively small size and rapid growth variations must arise very much more frequently than in more differentiated forms of life." (Stephenson, 1949).

These difficult issues are now tractable problems.

Marine biology must remain guided by the program so clearly seen by Ritter and Vaughan. That is, progress in understanding open ocean and deep-sea life can only be made by those who conduct or participate in research programs entailing both field and laboratory studies. Our oceanographic institutions will need to continue to foster shipboard research, ocean engineering, and ROV development. The understanding of the relationship between organisms and their environment cannot be achieved in the laboratory alone. The full variety of environments in the ocean has barely been explored. The new tools of global positioning systems, swath bathymetry, and ship maneuvering enable ships to find, revisit, and stay over unusual habitats. These tools enable unprecedented opportunities for sampling the diverse habitats of the sea. To take full advantage of this, shipboard facilities for biological research must be renewed on an ongoing basis.

Governments fund scientific research to provide for a better national defense, maintain a reliable food supply, eliminate pain and suffering through a better understanding of biological processes and drug discovery, preserve the quality of the environment, and simply further our understanding of life on Earth. Marine microbiology will increasingly continue to contribute to all of these endeavors.

\section{Acknowledgements}

My sincere thanks go to Michael Latz and Marianne Maggini for critical comments and to Deborah Day, archivist at the Scripps Institution of Oceanography library. I offer an apology to those whose work I did not mention or have slighted in any way. Finally, I particularly thank all SIO microbiologists whose work over the past one hundred years makes writing this short essay a delight.

\section{References}

Agassiz, A. and G.R. Agassiz, 1913: Letters and Recollections of Alexander Agassiz with a Sketch of His Life and Work. Houghton Mifflin, Boston, 454 pp.

Bartlett, D.H. 2002. Pressure effects on in vivo microbial processes. Biochim. Biophys. Acta, 1595, 367-381.

Benecke, W., 1933: Bakteriologie des Meeres. Handb. biolog. Arbeitsmeth., 9, 717-854.

Benson, A. and M. Calvin, 1947: The dark reductions of photosynthesis. Science, 105(2738), 648-649.
Bernhard, J.M., P.T. Visscher, and S S. Bowser, 2003: Submillimeter life positions of bacteria, protists, and metazoans in laminated sediments of the Santa Barbara Basin. Limnol. Oceanogr., 48(2), 813-828.

Bezdek, H.F. and A.F. Carlucci, 1972: Surface concentration of marine bacteria. Limnol. Oceanogr., 17(4), 566-569.

Blanchard, D.C. and L. D. Syzdek, 1990: Apparatus to determine the efficiency of transfer of bacteria from a bursting bubble to the jet drops. Limnol. Oceanogr. 35(1), 136-143.

Brahamsha, B. 1996. An abundant cell-surface polypeptide is required for swimming by the nonflagellated marine cyanobacterium Synechococcus. Proc. Natl. Acad. Sci. USA, 93(13), 6504-6509.

Buzzati-Traverso, A.A., 1958: Perspectives in Marine Biology. In: Perspectives in Marine Biology. Adriano A. Buzzati-Traverso, eds., University of California Press, Berkeley, California, 613-621.

Calvin, M. and A.A. Benson. 1949: The path of carbon in photosynthesis IV: The identity and sequence of the intermediates in sucrose synthesis. Science, 109 (2824), 140-142.

Campbell, B.J., C. Jeanthon, J.E. Kostka, G.W. Luther and S.C. Cary, 2001: Growth and phylogenetic properties of novel bacteria belonging to the epsilon subdivision of the Proteobacteria enriched from Alvinella pompejana and deep-sea hydrothermal vents. Appl. Environ. Microbiol., 67(10), 4566-4572.

Cary, S.C., M.T. Cottrell, J.L. Stein, F. Camacho and D. Desbruyeres, 1997: Molecular identification and localization of filamentous symbiotic bacteria associated with the hydrothermal vent annelid Alvinella pompejana. Appl. Environ. Microbiol., 63(3), 1124-1130.

Cooney, R.V., 1981: The metabolism of arsenic by marine organisms. University of California, San Diego, xii, $92 \mathrm{pp}$.

Cooper, L.H.N., 1937: The nitrogen cycle in the sea. J. Mar. Biol. Assoc. U.K., 22, 183-204.

DeLong, E.F., 1992: Archaea in coastal marine environments. Proc. Natl. Acad. Sci. USA, 89(12), 5685-5689.

DeLong, E.F., 2001: Microbial seascapes revisited. Cur. Opin. Micro., 4(3), 290-295.

Distel, D.L. and H. Felbeck, 1988a: Pathways of inorganic carbon fixation in the endosymbiont-bearing lucinid clam Lucinoma-aequizonata: 1. Purification and characterization of the endosymbiotic bacteria. J. Exp. Zool., 247(1), 1-10.

Distel, D.L. and H. Felbeck, 1988b. Pathways of inorganic carbon fixation in the endosymbiont-bearing lucinid clam Lucinoma-aequizonata: 2. Analysis of the individual contributions of host and symbiont cells to inorganic carbon assimilation. J. Exp. Zool., 247(1), 11-22.

Engebrecht, J. and M. Silverman, 1984: Identification of 
genes and gene-products necessary for bacterial bioluminescence. Proc. Natl. Acad. Sci. USA, 81(13), 4154-4158.

Felbeck, H., 1981. Chemoautotrophic potential of the hydrothermal vent tube worm, Riftia pachyptila Jones (Vestimentifera). Science, 213(4505), 336-338.

Fuhrman, J.A., 1999: Marine viruses and their biogeochemical and ecological effects. Nature, 399(6736), 541-548.

Fuhrman, J.A. and F. Azam, 1982: Thymidine incorporation as a measure of heterotrophic bacterioplankton production in marine surface watersEvaluation and field results. Mar. Biol., 66(2), 109-120.

Fuller, R.C., 1999: Forty years of microbial photosynthesis research: Where it came from and what it led to. Photosyn. Res., 62(1), 3-29.

Gee, H., 1932a: Bacteriological water sampler. Bull. Scripps Inst. Oceanog., Tech. Ser., 3(8), 191-200.

Gee, H., 1932b: Calcium equilibrium in sea water: I. Theoretical considerations. Bull. Scripps Inst. Oceanog., Tech. Ser., 3(7), 145-157.

Gee, H., 1932c: Calcium equilibrium in sea water: V. Preliminary experiments on precipitation by removal of carbon dioxide under aseptic conditions. Bull. Scripps Inst. Oceanog., Tech. Ser., 3(7), 180-187.

Goericke, R. and N.A. Welschmeyer, 1993: The marine prochlorophyte Prochlorococcus contributes significantly to phytoplankton biomass and primary production in the Sargasso Sea. Deep-Sea Res. I, 40(11-12), 2283-2294.

Hastings, J.W. and K.H. Nealson, 1977: Bacterial bioluminescence. Ann. Rev. Microbiol., 31, 549-595.

Jannasch, H.W. and G.E. Jones, 1959: Bacterial populations in sea water as determined by different methods of enumeration. Limnol. Oceanogr., 4(2), 128-139.

Kamen, M.D. 1985: Radiant Science, Dark Politics. A Memoir of the Nuclear Age. University of California Press, Berkeley, 348 pp.

Karl, D.M., 1995: Ecology of free-living, hydrothermal vent microbial communities. In: The Microbiology of Deep-Sea Hydrothermal Vents. The Microbiology of Extreme and Unusual Environments, D. M. Karl, ed., CRC Press, Boca Raton, Florida, 35-124.

Kluyver, A.J. 1959: Unity and diversity in the metabolism of micro-organisms. In: Albert Jan Kluyver, His Life and Work: Biographical Memoranda, Selected Papers, Bibliography and Addenda. A. F. Kamp, J. W. M. La Reviére, and W. Verhoeven, eds., NorthHolland Pub. Co., Amsterdam, 186-210.

Knowles, F.C. and A.A. Benson, 1983: The Biochemistry of Arsenic. Trends Biochem. Sci., 8(5), 178-180.

Kofoid, C.A. 1897. On some important sources of error in the plankton method. Science, 6(153), 829-832.

Kofoid, C.A. 1934: The distribution of the pelagic cili- ates in the eastern tropical Pacific. In: Proceedings of the Fifth Pacific Science Congress, Canada. Pacific Science Association. National Research Council of Canada. June 1-4, 1933 Vancouver, B.C. University of Toronto Press, Toronto, Canada.

Lappin-Scott, H.M., 2000: Claude E. ZoBell-Pioneer Microbial Ecologist. In: Microbial Biosystems: New Fronteirs. Proceedings of the 8th Eighth International Symposium on Microbial Ecology. C. R. Bell, M. Brylinsky, and P. Johnson-Green, eds., Atlantic Canada Society for Microbial Ecology, Halifax, Canada, 43-69.

Levin, L.A., 1994: Paleoecology and Ecology of Xenophyophores. Palaios, 9(1), 32-41.

Lewin, R.A., 2002: Prochlorophyta-A matter of class distinctions. Photosynthesis Research, 73(1-3), 59-61.

Lloyd, B., 1931: Bacterial denitrification: An historical and critical survey. J. Roy.Tech. Coll., Glasgow, 3, 530-550.

MacIntyre, F., 1974: The top millimeter of the ocean. Sci. Am., 230, 62-77.

McClung, L.S. and K.F. Meyer, 1974: Beginnings of bacteriology in California. Bacteriol. Rev., 38(3), 251-271.

McGraw, D.J., 2002: Claude ZoBell, Hadal Bacteria, and the "Azoic Zone." In: Oceanographic History: The Pacific and Beyond. K.R. Benson and P F. Rehbock, eds., University of Washington Press, Seattle, 259-270.

Mills, E.L., 1989: Biological Oceanography. Cornell University Press, Ithaca, New York, xvii, 368 pp.

Rittenberg, S.C., 1940: Bacteriological analysis of some long cores of marine sediments. J.Mar.Res., 3, 191-201.

Ritter, W.E., 1912: The Marine Biological Station of San Diego. Its history, present conditions, achievements, and aims. Univ. Calif. Pub. Zool., 9(4), 137-248.

Ritter, W.E., 1936: The Name, "Scripps Institution of Oceanography." Science, 84, 83.

Russell, H.L., 1893a: Bacteriology in its general relations. Am. Nat., 27, 847-859.

Russell, H.L., 1893b: Bacteriology in its general relations (continued). Am. Nat., 27, 1050-1065.

Sedgwick, W.T., 1901: The origin, scope and significance of bacteriology. Science, 13(317), 121-128.

Smith, C.R., L.A. Levin and L.S. Mullineaux, 1998: Deep-sea biodiversity: A tribute to Robert R. Hessler. Deep Sea Res. II, 45(1-3), 1-11.

Spiess, F.N. 2002: Charles Kofoid's Role in Establishing the Scripps Institution of Oceanography. In: Oceanographic History: The Pacific and Beyond. K. R. Benson and P. F. Rehbock, eds., University of Washington Press, Seattle, 7-16.

Steemann Nielsen, E., 1952: Use of radio-active carbon $\left({ }^{14} \mathrm{C}\right)$ for measuring organic production in the sea. $J$. Cons. Int. Explor. Mer, 18, 117-140. 
Stein, J.L., S.C. Cary, R.R. Hessler, S. Ohta, R.D. Vetter, J.J. Childress and H. Felbeck. 1988. Chemoautotrophic symbiosis in a hydrothermal vent castropod. Biol. Bull., 174(3), 373-378.

Stephenson, M., 1949: Bacterial Metabolism (3rd ed.). London, Longmans, Green and Company, xiv, 398 pp.

Sweeney, B.M., 1954: Gymnodinium splendens: A marine dinoflagellate requiring vitamin B-12. Am.J.Bot., 41(10), 821-824.

Sweeney, B.M. and J.W. Hastings, 1957: Characteristics of the diurnal rhythm of luminescence in Gonyaulax polyedra. J. Cellular Comp. Physiol., 49, 115-128

Sweeney, B.M. and F.T. Haxo, 1961: Persistence of a photosynthetic rhythm in enucleated Acetabularia. Science, 134(3487), 1361-1363.

Tendal, O.S. and RR. Hessler, 1977: An introduction to the biology and systematics of Komokiacea (Textulariina, Foraminiferida). Galathea Reports, 14, 165-194.

van Iterson, G., L.E. den Dooren de Jong, and A.J. Kluyver, 1983: Martinus Willem Beijerinck, his life and his work. Science Tech, Madison, Wis., xxix, 181 pp.

Vaughan, T.W., 1926a: Biological research at the Scripps Institution of Oceanography. Science, 63, 297.

Vaughan, T.W., 1926b: Oceanographic investigations of the Scripps Institution for Biological Research of the University of California. Science, 63, 8-10.

Vaughan, T.W., 1930: The oceanographic point of view. In: Contributions to Marine Biology. Lectures and symposia given at the Hopkins Marine Station, December 20-21, 1929, at the midwinter meeting of the Western Society of Naturalists. Stanford University Press, Palo Alto, California, 40-56.
Waksman, S.A. 1946. Sergei Nikolaevitch Winogradsky. September 1, 1856-August 31, 1946. The story of a great bacteriologist. Soil Sci., 62, 197-226.

Waksman, S.A. and C.E. Renn, 1936: Decomposition of organic matter in sea water by bacteria. III. Factors influencing the rate of decomposition. Biol.Bull., 70, 472-483.

Williams, P.M., A.F. Carlucci, S.M. Henrichs, E S. Van Vleet, S.G. Horrigan, F.M.H. Reid, and K.J. Roberston, 1986: Chemical and microbiological studies of sea-surface films in the southern Gulf of California and off the west coast of Baja California. Mar.Chem., 19, 17-98.

Yayanos, A.A. 2000a: High-pressure habitats. In: Encyclopedia of Microbiology,(v. 2, 2nd ed.), J. Lederberg, ed., 2,664-2676.

Yayanos, A.A. 2000b: ZoBell and his contributions to piezobiology (barobiology). In: Microbial Biosystems: New Fronteirs. Proceedings of the 8th Eighth International Symposium on Microbial Ecology. C.R. Bell, M. Brylinsky, and P. Johnson-Green, eds., Atlantic Canada Society for Microbial Ecology, Halifax, Canada, 689-694.

ZoBell, C.E., 1946: Marine Microbiology. Chronica Botanica Co., Waltham, Massachusetts, xv, 240 pp.

ZoBell, C.E., 1968: In: Marine Biology IV. Proceedings of the Fourth International Interdisciplinary Conference. Unresolved Problems in Marine Microbiology. C.H. Oppenheimer, eds., New York Academy of Sciences, New York, 25.

ZoBell, C.E. and H.M. Mathews, 1936: A Qualitative Study of the Bacterial Flora of Sea and Land Breezes. Proc. Natl. Acad. Sci. USA, 22(10), 567-572.

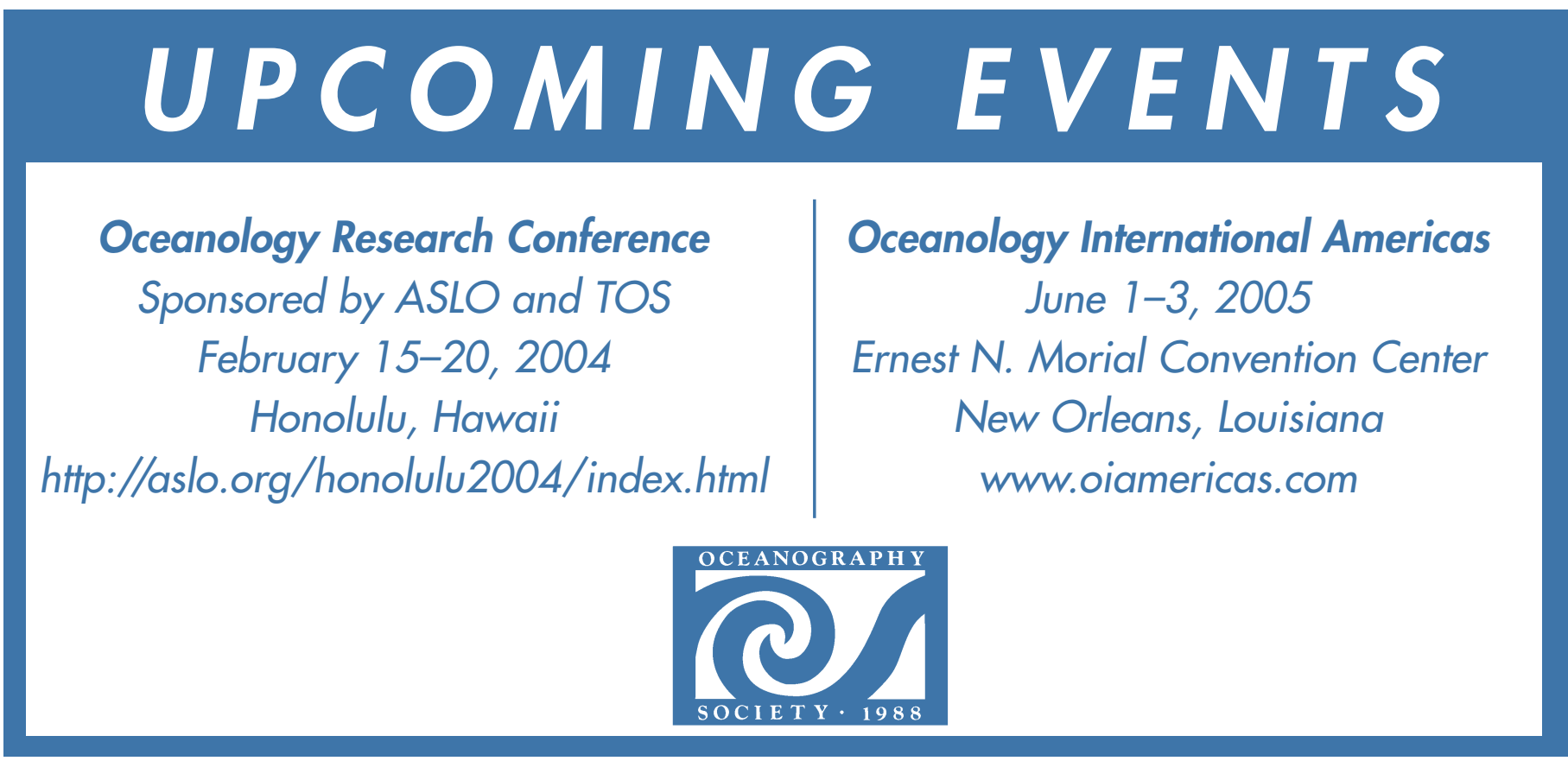

